\title{
Kepuasan Kerja Tinggi Pada Mental Workload Yang Tinggi: Studi Korelasi Di Hotel "X"
}

\author{
Ellen Violetta Nainggolan, \\ Listiyani Dewi Hartika ${ }^{1}$ \\ Program Studi Psikologi \\ Universitas Dhyana Pura Bali \\ J1. Raya Padang Luwih, Dalung, Kuta utara, Bali \\ ${ }^{1}$ e-mail: listiyani.dh@gmail.com
}

\begin{abstract}
The increasing amount of hotels in Bali may cause tougher competition among existing hotels. Human resources as organization activator will have an extra workload, such as increasing customer service quality and being an informal marketer. This situation can cause high mental workload felt by the staff. High mental workload is not always balanced by low job satisfaction, as with high mental workload can urge the staff to achieve higher performance and feel work satisfaction. Therefore, researcher wanted to intensively find out the relationship between mental workload and job satisfaction measured with scales designed by the researcher, interview and observation with 52 staff as samples. The result shows that there is a positive relationship between mental workload and job satisfaction $(r=.688 ; p=0.000)$. In other words, whenever mental workload is high, job satisfaction will also be high.
\end{abstract}

Keywords: mental workload; job satisfaction

Abstrak - Pertambahan jumlah hotel di Bali menyebabkan persaingan antar hotel yang ada semakin berat. SDM (sumber daya manusia) sebagai penggerak perusahaan pun tidak jarang akan menerima beban kerja tambahan, seperti meningkatkan kualitas layanan kepada para konsumen dan menjadi pemasar informal. Hal tersebut dapat memicu tingginya beban kerja mental (mental workload) yang dirasakan oleh karyawan. Mental workload yang tinggi tidak selalu diimbangi dengan rendahnya kepuasan kerja, karena dengan mental workload yang tinggi dapat memacu karyawan untuk bekerja lebih baik dan merasakan kepuasan kerja. Oleh karena itu peneliti ingin meneliti lebih intensif tentang hubungan mental workload dengan kepuasan kerja karyawan di hotel "X" Kerobokan, Bali. Mental workload dan kepuasan kerja diukur dengan skala yang disusun sendiri oleh peneliti, wawancara dan observasi dengan total sampel penelitian 52 orang karyawan. Hasil penelitian menunjukkan ada hubungan yang positif antara mental workload dengan kepuasan kerja $(r=.688 ; p=0.000)$. Artinya, saat mental workload karyawan tinggi, kepuasan kerja yang dirasakan juga tinggi.

Kata kunci: beban kerja mental; kepuasan kerja 


\section{PENDAHULUAUN}

Sektor pariwisata di Bali merupakan sektor yang sedang berkembang dan memiliki peran penting bagi tersedianya lapangan pekerjaan. Hal ini terjadi secara khusus pada sektor perhotelan, yang mengalami perkembangan setiap tahunnya. Data perkembangan jumlah kamar hotel di Bali menurut Badan Pusat Statistik (BPS, 2015) dapat dilihat pada tabel berikut:

Tabel 1.

Perkembangan Jumlah Kamar Hotel di Bali Tahun 2011-2014

\begin{tabular}{ccc}
\hline Tahun & Tambahan Kamar & Total Kamar \\
\hline 2011 & & 22.000 \\
2012 & 3.400 unit & 25.400 \\
2013 & 4.700 unit & 30.200 \\
2014 & 4.100 unit & 34.000 \\
\hline TOTAL & 12.200 unit & \\
\hline
\end{tabular}

Tabel di atas menunjukkan bahwa setiap tahun terjadi penambahan jumlah kamar hotel, yang berarti pula persaingan antara hotel-hotel yang ada di Bali semakin berat. Dengan persaingan tersebut, SDM (sumber daya manusia) pun tidak jarang memiliki beban kerja tambahan, baik pada karyawan bagian back office ataupun service yang jam kerjanya diatur oleh shift.

Dampak perkembangan hotel yang sudah dijelaskan sebelumnya juga terjadi di hotel "X", yang merupakan salah satu hotel budget yang ada di Bali. Jam kerja yang berlaku di hotel "X" yaitu delapan jam kerja, tetapi tidak jarang beberapa karyawan bekerja lebih dari delapan jam karena pekerjaan mereka belum selesai di hari biasa. Lebih lanjut lagi keadaan berbeda terjadi pada saat high season, terutama karyawan pada bagian service akan bekerja lebih keras dari biasanya karena jumlah tamu yang meningkat (Pusat Data Divisi SDM, 2015).

Data temuan melalui hasil wawancara pada salah seorang karyawan berinisial MN (komunikasi pribadi, 2015) bagian housekeeping menunjukkan bahwa satu orang karyawan harus membersihkan dan merapikan 8 hingga 10 kamar dalam satu harinya. Hal ini dapat memperjelas bagaimana tingginya tuntutan dan beban tugas yang diperoleh karyawan, khususnya pada masa libur panjang. Sedangkan menurut informasi yang secara terpisah disampaikan oleh Head of Housekeeping Department (komunikasi pribadi, 2015) secara normal seharusnya pada setiap harinya atau pada setiap shift kerjanya satu orang karyawan dapat menyelesaikan maksimum 5 sampai dengan 6 kamar untuk hasil yang baik. Menimbang kegiatan membersihkan kamar tidak hanya semata-mata menyapu dan 
mengepel namun juga melibatkan kegiatan penataan kamar secara keseluruhan, penataan tempat tidur, penataan dan pembersihan kamar mandi, termasuk juga penyediaan kelengkapan kamar.

Kondisi yang diungkapkan mengindikasikan tidak jarang karyawan pulang 1 hingga 2 jam lebih lama dari jam kerja normal. Hal serupa kembali diungkapkan oleh salah satu karyawan pada bagian dapur juga mengalami kondisi yang hampir sama. Seperti yang sempat diungkapkan oleh salah seorang narasumber berinisial WY (komunikasi pribadi, 2015) yang mengatakan bahwa jumlah karyawan yang bekerja dalam 1 hari yaitu dua hingga tiga orang karyawan. Mereka bertugas untuk menangani makan pagi, tea/coffee time, sampai makan siang tamu. Artinya bahwa dua orang tersebut akan memiliki jumlah pekerjaan yang meningkat terlebih jika tamu sedang dalam jumlah banyak atau permintaan tamu beragam. Kondisi ini tentunya akan memberi dampak yang cukup signifikan pada tingkat kelelahan fisik dan juga mental, karena selain melayani mereka juga harus tetap memperhatikan permintaan tamu dan menangani keluhan atau pertanyaan tamu berkait dengan layanan yang mereka berikan.

Selain bekerja dengan kekuatan otot, karyawan juga dituntut untuk memikirkan cara mengatur prioritas kerja, memilih alat dan metode kerja yang cepat dan tepat di saat beban kerja bertambah dalam batasan waktu yang singkat, serta menyelesaikan permasalahan yang berkait dengan tugas atau pekerjaannya. Karyawan yang bekerja pada bagian housekeeping harus mengerti betul cara menggunakan alat-alat dan obat-obatan yang tersedia agar tidak melukai siapapun, karena masingmasing alat dan obat memiliki fungsi tersendiri. Tuntutan aktivitas mental tidak hanya dirasakan oleh karyawan housekeeping, tetapi juga karyawan pada bagian dapur. Karyawan tidak hanya berfokus untuk menyiapkan hidangan yang lezat namun dituntut juga untuk dapat mengatur administrasi pada bagiannya.

\section{Mental Workload}

Mental workload ialah konstruk mental yang mencerminkan ketegangan mental akibat melakukan tugas di bawah kondisi lingkungan dan operasional tertentu, ditambah dengan kemampuan karyawan untuk menanggapi tuntutan (Cain, 2007). Hal tersebut dapat dilihat dari bagaimana karyawan

memandang pekerjaan mereka melalui beberapa dimensi, yaitu physical demand, mental demand, temporal demand, performance, dan frustration level (Hart \& Staveland, 1988).

Setiap dimensi tersebut memiliki dampak yang dapat menyebabkan karyawan merasa terbebani secara mental, tetapi bukan berarti dapat membuat karyawan menjadi tidak produktif lagi dalam bekerja. Karyawan yang merasakan mental workload tinggi seringkali juga merasa bahwa hal tersebut 
dapat memacunya untuk dapat menyelesaikan pekerjaannya dengan lebih baik dan merasakan kepuasan.

Hasil penelitian Dhania (2010) menunjukkan bahwa banyak hal yang dapat menjadi pendorong untuk dapat merasakan kepuasan kerja, salah satunya ialah karena stres kerja yang tinggi membuat karyawan terpacu untuk melakukan tugasnya sebaik mungkin sehingga mampu merasakan puas dengan pekerjaannya. Sejalan dengan penelitian sebelumnya, McGee, Goodson dan Cashman (dalam Dhania, 2010) mendapati bahwa terdapat beberapa faktor yang menyebabkan pegawai mengalami stres kerja tetapi masih merasa puas terhadap pekerjaannya, diantaranya disebabkan oleh tugas yang mereka kerjakan penuh dengan tantangan dan menyenangkan hati mereka.

Berdasarkan hasil penelitian sebelumnya yang dilakukan oleh Dhania (2010), dapat diketahui bahwa stres tidak hanya membawa dampak yang negatif terhadap kinerja karyawan. Stres digolongkan menjadi 2 jenis yaitu distress dan eustress. Distress yaitu hasil respon terhadap stres yang bersifat tidak sehat, negatif, dan destruktif (bersifat merusak); sedangkan eustress yaitu hasil respon terhadap stres yang bersifat sehat, positif, dan konstruktif (bersifat membangun) (Quick \& Quick, 1984). Berdasarkan penjelasan tersebut dapat dilihat bahwa saat karyawan merasa terbebani secara mental, karyawan dikatakan mengalami eustress dimana hal tersebut dapat memunculkan suatu kondisi kepuasan dalam pekerjaannya.

Penelitian yang relevan antara mental workload dan kepuasan kerja pernah dilakukan oleh Baroka (2013) terhadap karyawati yang sudah berkeluarga dan bekerja di pabrik. Penelitian itu menunjukkan adanya hubungan negatif antara mental workload dengan kepuasan kerja, yang artinya semakin tinggi beban kerja maka kepuasan kerja akan menurun. Hal ini didukung juga dengan penelitian yang dilakukan oleh Mustapha dan Ghee (2013) terhadap staf akademis di sebuah sekolah tinggi di Kelantan, Malaysia, yang memberikan hasil bahwa terdapat hubungan negatif yang signifikan antara workload dengan kepuasan kerja. Pendapat serupa dikemukakan oleh Altaf dan Awan (2011) pada penelitian yang dilakukan terhadap beberapa orang pekerja dari organisasi yang berbeda di kawasan Islamabad, yang menemukan bahwa workload yang tinggi memiliki pengaruh yang negatif terhadap kepuasan kerja.

Terkait dengan paragraf di atas, pada penelitian ini ditemukan data di hotel " $\mathrm{X}$ " bahwa saat mental workload tinggi, berdampak pada keluarnya karyawan (turnover) yang terkait dengan aspek kepuasan kerja pada 2013. Berikut tabel jumlah karyawan yang keluar terkait aspek kepuasan kerja. 
Tabel 2.

Jumlah Karyawan Keluar Terkait Aspek Kepuasan Kerja 2013

\begin{tabular}{lc}
\hline Aspek kepuasan kerja & Jumlah karyawan \\
\hline Pay & 18 orang \\
Coworker & 4 orang \\
Communication & 6 orang \\
Nature of work & 3 orang \\
\hline \multicolumn{1}{c}{ TOTAL } & 31 orang \\
\hline
\end{tabular}

\section{Kepuasan Kerja}

Kepuasan kerja adalah sikap yang merefleksikan bagaimana perasaan individu mengenai pekerjaannya, baik secara keseluruhan maupun dari berbagai aspek pekerjaan (Spector, 1997). Perasaan tersebut berkisar antara kesukaan atau kepuasan terhadap pekerjaannya, dan ketidaksukaan atau ketidakpuasan terhadap pekerjaannya. Adapun aspek-aspek yang menyusun kepuasan kerja menurut Spector (1997) yaitu pay, promotion, supervision, fringe benefit, contingent reward, operation conditioning, coworker, nature of work, dan communication.

Aspek-aspek tersebut saling melengkapi dan mempengaruhi kepuasan kerja yang dirasakan karyawan. Oleh karena itu, jika karyawan merasa tidak puas terhadap salah satu aspek, belum dapat dikatakan bahwa karyawan tersebut merasa tidak puas terhadap pekerjaannya. Justru ada aspek-aspek lain dari kepuasan kerja yang perlu diperhatikan.

Salah satu karyawan mengatakan bahwa bekerja dengan orang-orang yang sudah lama bergabung di hotel " $\mathrm{X}$ " lebih menyenangkan, karena hubungan yang terjalin sudah sangat dekat dan hal tersebut dapat membuat karyawan merasa tidak tertekan dan tidak stres (AD, komunikasi pribadi, 2015). Selain itu juga ada karyawan yang mengatakan bahwa peran atasan adalah salah satu yang membuat ia senang bekerja di hotel " $X$ ". Atasan memberikan pengawasan yang baik, bahkan saat karyawan mengalami kesusahan, mereka dapat bertanya dan akan dibantu untuk mencari jalan keluar dari masalah tersebut (KT, komunikasi pribadi, 2015). Salah satu karyawan lain mengatakan bahwa ia puas dengan promosi yang didapatkan. Maka dari itu, ia sudah mendapatkan posisi yang baik dalam perusahaan dan karyawan merasa senang bekerja di hotel tersebut (DN, komunikasi pribadi, 2015).

Salah satu karyawan mengatakan bahwa ia juga merasakan adanya mental workload dari pekerjaannya (PN, komunikasi pribadi, 2015). Akan tetapi bedasarkan dari hasil wawancara awal yang peneliti lakukan diperoleh data bahwa sebagian besar karyawan lain merasa adanya mental workload yang tinggi, hanya saja karyawan tetap menikmati pekerjaannya. Dengan kata lain, karyawan tetap 
merasa bahwa pekerjaannya menyenangkan, dan mental workload tersebut tidak berpengaruh terhadap cara karyawan memandang pekerjaannya.

Berdasarkan data dan penjelasan sebelumnya, bertitik-tolak dari pentingnya kepuasan kerja dalam kaitannya dengan mental workload, maka penelitian ini bertujuan untuk melihat sejauh mana mentalworkload memiliki hubungan terhadap kepuasan kerja karyawan di hotel " $\mathrm{X}$ ".

\section{METODE}

\section{Partisipan}

Partisipan dalam penelitian ini adalah karyawan hotel X. Teknik pengambilan sampel menggunakan metode proportional random sampling, dimana jumlah populasi sebanyak 60 orang dan yang digunakan sebagai sampel sebanyak 52 orang. Jumlah tersebut dipilih dengan tujuan untuk mendapatkan jumlah sampel yang ideal, sesuai dengan yang dikemukakan oleh Krejcie dan Morgan (1970) bahwa dengan jumlah populasi 60 orang, maka sampel idealnya adalah 52 orang. Alasan lainnya adalah agar masing-masing departemen dapat terwakilkan dan mendapatkan kesempatan yang sama dalam menyumbangkan sampel.

\section{Desain}

Penelitian ini tergolong tipe penelitian kuantitatif dengan metode korelasional. Data akan diambil dengan menggunakan skala yang dituangkan dalam beberapa pernyataan dalam sebuah kuesioner. Pengolahan data nantinya akan dilakukan secara statistik.

\section{Prosedur}

Peneliti mengembangkan alat ukur sendiri untuk masing-masing variabel. Setelah alat ukur selesai disusun, peneliti melakukan uji validitas dan reliabilitas alat ukur terlebih dahulu. Selanjutnya dilakukan pengambilan data pada sampel yang dilanjutkan dengan uji korelasi untuk memperoleh hasil akhir. Sebagai tambahan data yang fungsinya memperkuat temuan, peneliti melakukan observasi dan wawancara kepada sampel. Adapun prosedur distribusi alat ukurnya adalah dalam proses uji coba peneliti menyebarkan alat ukur awal kepada karyawan hotel budget lainnya di kawasan Nusa Dua, Bali. Setelah diperoleh data hasil uji coba dan didapatkan alat ukur akhir, peneliti menyebarkan alat ukur 
tersebut ke setiap departemen di tempat penelitian dengan ditemani oleh masing-masing kepala departemen.

Peneliti menggunakan mental workload sebagai variabel pertama dan kepuasan kerja sebagai variabel kedua. Pengukuran pada kedua variabel dilakukan dengan menggunakan skala Likert yang disusun sendiri oleh peneliti. Pengukuran mental workload terdiri dari 19 butir pernyataan dan kepuasan kerja terdiri dari 44 butir pernyataan dengan 5 alternatif jawaban yaitu SS (sangat setuju), S (setuju), R (ragu-ragu), TS (tidak setuju), dan STS (sangat tidak setuju).

Mental workload yang dimaksud dalam penelitian ini adalah skor dari dimensi mental workload yang terkait dengan beban kerja mental yang dirasakan oleh karyawan dalam bekerja. Adapun dimensi tersebut adalah: (1) physical demand (kebutuhan fisik), ditandai dengan besaran kekuatan fisik yang diperlukan, kecepatan gerak, serta efek pekerjaan pada fisik karyawan; (2) mental demand (kebutuhan mental), ditandai dengan adanya aktivitas berpikir, pola pikir sederhana atau kompleks dalam menyelesaikan tugas, efek pekerjaan pada mental karyawan; (3) temporal demand (tuntutan waktu), ditandai dengan besaran waktu yang diperlukan dalam menyelesaikan tugas, kecocokan terhadap waktu kerja, serta efek tekanan waktu terhadap kinerja karyawan; (4) performance (kinerja), ditandai dengan cara pandang karyawan mengenai kesuksesan karyawan saat ini, dan kepuasan terhadap kinerja; (5) effort (usaha), ditandai dengan pandangan mengenai usaha yang diperlukan karyawan dalam bekerja, serta kepuasan terhadap usaha yang dilakukan; dan (6) frustration level (tingkat stres), ditandai dengan besaran perasaan bosan, putus asa, kemarahan terhadap tugas dan tanggung jawab karyawan.

Pada pengukuran mental workload, terdiri dari 19 butir yang sudah diuji kembali dan diperoleh nilai validitas antara .318 hingga .679. Seluruh hasil korelasi memiliki nilai diatas .25. Maka dapat dinyatakan seluruh butir dalam penelitian ini valid. Sementara hasil uji reliabilitas sebesar .885 yang berarti alat ukur yang digunakan dalam penelitian ini dinyatakan reliabel untuk mengukur mental workload.

Sementara kepuasan kerja adalah sikap yang merefleksikan bagaimana perasaan individu mengenai pekerjaannya, baik secara keseluruhan maupun dari berbagai aspek pekerjaan. Perasaan tersebut berkisar antara kesukaan atau kepuasan terhadap pekerjaannya, dan ketidaksukaan atau ketidakpuasan terhadap pekerjaannya (Spector, 1997). Adapun aspek penyusun kepuasan kerja sebagai berikut: (1) pay (upah), ditandai dengan kepuasan karyawan terhadap gaji yang diterima, dan kebijakan penggajian dari perusahaan; (2) promotion (promosi), ditandai dengan kepuasan karyawan terhadap kesempatan promosi yang diterima, dan kebijakan promosi yang berlaku; (3) supervision (supervisi), ditandai dengan kepuasan yang dirasa karyawan terhadap kecakapan atasan, cara pengawasan yang 
diberikan, dan keadilan atasan; (4) fringe benefit (tunjangan), ditandai dengan kepuasan karyawan terhadap keuntungan yang diterima dari perusahaan, dan kepuasan terhadap tunjangan; (5) contingent reward (penghargaan), ditandai dengan kepuasan karyawan terhadap apresiasi perusahaan dengan pekerjaan yang dilakukan karyawan, dan kepuasan terhadap kebijakan penghargaan yang diterima; (6) operation conditioning (prosedur operasional), ditandai dengan kepuasan terhadap kebijakan terhadap aturan yang berlaku, dan prosedur pelaksanaan di perusahaan; (7) coworker (rekan kerja), ditandai dengan kepuasan yang dirasa karyawan terhadap kecocokan relasi dengan rekan kerja, dan penilaian terhadap rekan kerja; (8) nature of work (karakteristik pekerjaan), ditandai dengan kepuasan yang dirasa karyawan terhadap makna pekerjaan yang dijalani, dan kesukaan terhadap pekerjaan; dan (9) communication (komunikasi), ditandai dengan kepuasan yang dirasa oleh karyawan terhadap keefektifan penyampaian informasi, dan pola komunikasi yang ada di perusahaan.

Pada pengukuran kepuasan kerja, terdiri dari 44 butir yang sudah diuji kembali dan diperoleh nilai validitas di antara .388 hingga .702. Maka dapat dinyatakan seluruh butir dalam penelitian ini valid. Sementara itu, hasil uji reliabilitas sebesar .950 yang berarti alat ukur yang digunakan dalam penelitian ini dinyatakan reliabel untuk mengukur kepuasan kerja.

\section{Teknik Analisis}

Data yang diperoleh akan diukur dan disajikan secara kuantitatif. Data penelitian dianalisis secara statistik menggunakan software SPSS dengan melakukan uji korelasi Pearson Product Moment untuk mengetahui ada atau tidaknya hubungan antara mental workload dengan kepuasan kerja pada karyawan di hotel " $\mathrm{X}$ " serta untuk mengetahui seberapa erat hubungan kedua variabel beserta masingmasing dimensi dan aspeknya.

\section{ANALISIS DAN HASIL}

\section{Karakteristik Partisipan}

Partisipan dalam penelitian ini adalah karyawan Hotel " $X$ ", yang berasal dari delapan departemen yaitu human resources, accounting, housekeeping, food and beverage product, food and beverage service, sales and marketing, front office, dan engineering. Total karyawan (populasi) dari hotel "X" adalah sebanyak 60 orang yang kemudian diambil 52 orang sebagai subjek penelitian (sampel). Pada 52 orang partisipan yang terlibat, terbagi menjadi 41 orang laki-laki dan 11 orang 
perempuan dengan tingkat pendidikan masing-masing sebagai berikut: SMA/SMK sebanyak 22 orang, Diploma sebanyak 11 orang, dan sarjana strata satu (S1) sebanyak 19 orang. Jika ditinjau dari masa kerja, karakteristik partisipan yang terlibat adalah sebagai berikut: masa kerja kurang dari 1 tahun sebanyak 9 orang, 1 hingga 2 tahun sebanyak 22 orang, lebih dari 2 hingga 3 tahun sebanyak 21 orang.

\section{Hasil Uji Normalitas dan Linearitas}

Berdasarkan uji normalitas dengan menggunakan teknik Kolmogorov-Smirnov, diperoleh hasil nilai signifikansi sebesar .327; sementara pada kepuasan kerja diperoleh nilai signifikansi sebesar 847 . Kesimpulannya adalah kedua variabel memiliki data yang berdistribusi secara normal,yang berarti data dapat digeneralisasikan atau dianggap sampel dapat mewakili seluruh keberadaan atau karakteristik populasi.

Berdasarkan uji linearitas, diperoleh hasil signifikansi sebesar .748. Kesimpulannya adalah kedua variabel memiliki hubungan yang linear.

\section{Hasil Uji Korelasi}

Tabel 3.

Hasil Uji Korelasi

\begin{tabular}{llcc}
\hline & & Mental Workload & Kepuasan Kerja \\
\hline Mental workload & Pearson Correlation & 1 & $.688^{* *}$ \\
& Sig. (2 tailed) & .000 \\
& $\mathrm{~N}$ & 52 & 52 \\
Kepuasan kerja & $\begin{array}{l}\text { Pearson Correlation } \\
\text { Sig. (2 tailed) }\end{array}$ & $.688^{* *}$ & 1 \\
& $\mathrm{~N}$ & .000 & 52 \\
\hline Keterangan: ** = correlation is significant at the 0.005 level (2-tailed)
\end{tabular}

Berdasarkan tabel hasil uji korelasi dengan teknik Pearson Product Moment, dapat dilihat bahwa mental workload memiliki hubungan searah yang kuat dengan variabel kepuasan kerja. Saat mental workload dirasakan tinggi oleh karyawan, maka akan diikuti dengan kepuasan kerja yang meningkat.

Selain itu dilakukan juga uji korelasi antara dimensi mental workload dan kepuasan kerja. Uji korelasi tersebut menunjukkan hasil bahwa seluruh dimensi berkorelasi positif dengan kepuasan kerja, serta dimensi temporal demand (tuntutan waktu) adalah dimensi yang memiliki hubungan paling kuat dengan kepuasan kerja dengan nilai korelasi sebesar .597 (lihat Tabel 5). Uji korelasi dilakukan 
kembali antara aspek kepuasan kerja dengan mental workload. Uji korelasi tersebut menunjukkan hasil bahwa seluruh aspek berkorelasi positif dengan mental workload, serta aspek pay (gaji) adalah aspek yang memiliki hubungan paling kuat dengan mental workload dengan nilai korelasi sebesar .529.

Tabel 4.

Hasil Uji Korelasi Dimensi Mental Workload Dengan Kepuasan Kerja

\begin{tabular}{|c|c|c|c|c|c|c|c|}
\hline & & 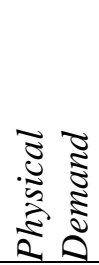 & 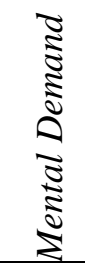 & 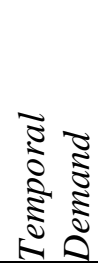 & 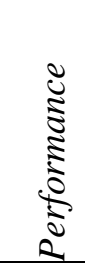 & $\sum_{0.10}^{5}$ & 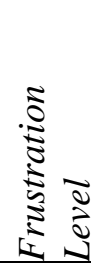 \\
\hline \multirow{2}{*}{$\begin{array}{l}\text { Kepuasan } \\
\text { Kerja }\end{array}$} & Pearson Correlation & .442 & .527 & .597 & .307 & .383 & .499 \\
\hline & Sig.(2tailed) & .000 & .000 & .000 & .027 & .005 & .000 \\
\hline
\end{tabular}

Tabel 5.

Hasil Uji Korelasi Aspek Kepuasan Kerja Dengan Mental Workload

\begin{tabular}{|c|c|c|c|c|c|c|c|c|c|c|}
\hline & & : & $\begin{array}{l}\overline{\tilde{o}} \\
\stackrel{\Xi}{0} \\
0\end{array}$ & 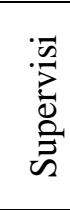 & 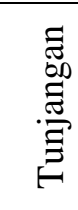 & 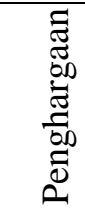 & 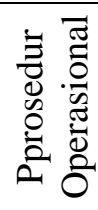 & 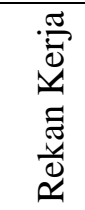 & 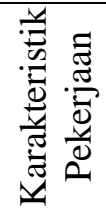 & 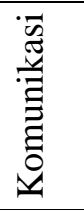 \\
\hline \multirow{5}{*}{$\begin{array}{l}\text { Mental } \\
\text { Workload }\end{array}$} & Pearson & .52 & .32 & .30 & .307 & .456 & .204 & .122 & .498 & .290 \\
\hline & Correlation & 9 & 2 & 6 & \multirow{4}{*}{.028} & \multirow{4}{*}{.001} & \multirow{4}{*}{.146} & \multirow{4}{*}{.389} & \multirow{4}{*}{.000} & \multirow{4}{*}{.037} \\
\hline & \multirow{3}{*}{ Sig.(2tailed) } & & & & & & & & & \\
\hline & & .00 & .00 & .02 & & & & & & \\
\hline & & 0 & 0 & 0 & & & & & & \\
\hline
\end{tabular}

\section{DISKUSI}

Setelah dilakukan penelitian pada hotel " $\mathrm{X}$ " mengenai hubungan antara variabel mental workload dan kepuasan kerja, ditemukan hasil bahwa ada hubungan yang signifikan antara dua variabel.

Dilihat dari hasil tersebut, maka dapat dikatakan adanya korelasi antara variabel mental workload dan kepuasan kerja. Korelasi tersebut lebih mengarah kepada korelasi positif, dimana saat karyawan merasa mental workload tinggi maka kepuasan kerja yang dirasakan juga tinggi.

Menurut Bruce (2013), semakin banyak kecakapan yang dibutuhkan dalam melakukan suatu pekerjaan, semakin puas karyawan tersebut. Dengan besarnya beban tugas yang diemban maka 
semakin besar juga tanggung jawab yang dipikul oleh karyawan. Hal tersebut dapat memperkaya pekerjaan karyawan dan juga menumbuhkan moral kerja karyawan serta dapat membuat karyawan merasa lebih puas dalam bekerja. Korelasi positif mental workload dengan kepuasan kerja ini juga dapat diperjelas dengan pendapat yang dikemukaan oleh Jobe (dalam Bruce, 2013), dimana karyawan diberikan tugas yang lebih khusus dan gabungan tanggung jawab yang lebih besar dapat membuat karyawan secara otomatis meningkatkan diri dari pekerjaan mereka sebelumnya, sehingga ketika mereka berhasil mencapainya mereka akan merasa puas. Selain itu, jika ditelaah dari lingkungan kerja di Bali yang terkait dengan aspek budaya, kebiasaan masyarakat di Bali yang bersikap menerima pekerjaan sebagai suatu rutinitas membuat mereka mulai membiasakan diri dengan segala tuntutan pekerjaan yang ada, begitu pula dengan beban kerja yang berlebih. Mereka memunculkan perasaan puas bekerja sejauh mereka dapat menyelesaikan pekerjaannya dan tidak lagi melihat apakah beban kerjanya meningkat atau masih dalam batasan wajar.

Ditemukan bahwa dimensi temporal demand memiliki hubungan searah yang paling kuat dengan kepuasan kerja. Saat karyawan merasakan tuntutan waktu yang tinggi, dimana karyawan diburu waktu dalam menyelesaikan pekerjaannya dan karyawan tersebut berhasil menyelesaikan pekerjaannya dengan baik, karyawan semakin terpacu dalam bekerja dan dapat menjadi puas terhadap pekerjaan tersebut. Hal ini disebabkan karena apabila pekerja berhasil menuntaskan pekerjaan hari itu, maka hal tersebut akan sama dengan berhasil "menutup" beban tugas di hari bersangkutan sehingga esok mereka tidak harus menanggung sisa pekerjaan yang tertunda. Oleh karenanya, meskipun mereka diburu waktu dalam bekerja yang berarti temporal demand pada tugas mereka tinggi, ketika mereka berhasil menyelesaikannya tingkat kepuasan kerjanya juga akan ikut naik atau meningkat.

Selain itu, ditemukan bahwa aspek pay memiliki hubungan searah paling kuat dengan mental workload. Semakin puas karyawan terhadap gajinya, maka semakin cepat karyawan merasakan mental workload yang tinggi. Dikatakan bahwa penambahan gaji yang diterima oleh karyawan akan diikuti dengan bertambah besarnya beban kerja yang ditanggung oleh karyawan tersebut yang akhirnya menjawab bagaimanan kepuasan terhadap gaji memiliki hubungan paling kuat dengan mental workload.

Pada penelitian ini telah diperoleh temuan-temuan yang dapat memberi pemahaman baru tentang hubungan antara mental workload dengan tingkat kepuasan kerja pada karyawan, yang dalam hal ini berbeda dengan temuan pada penelitian sebelumnya, yaitu terdapat hubungan positif diantara kedua variabel penelitian. Selain itu juga diperoleh temuan bahwa semakin tinggi temporal demand, sebagai salah satu aspek mental workload, maka semakin tinggi pula tingkat kepuasan kerjanya, serta 
faktor gaji ikut menunjukkan korelasi yang positif dengan variabel mental workload. Namun hasil penelitian ini masih harus dikaji lagi pada penelitian berikutnya menimbang hasilnya kurang dapat digeneralisasikan secara luas karena penelitian ini dilakukan di sebuah hotel di Bali dengan tipikal hotel budget yang karakteristik dan kondisinya belum tentu sama dengan tempat kerja lain ataupun untuk model hotel serupa.

\section{SIMPULAN DAN SARAN}

\section{Simpulan}

Terdapat hubungan positif antara mental workload dengan kepuasan kerja, yang berkorelasi secara positif. Hal tersebut berarti semakin tinggi mental workload yang dirasakan oleh karyawan maka semakin tinggi juga kepuasan kerja karyawan tersebut.

Temporal demand merupakan dimensi dari mental workload yang memiliki hubungan paling kuat dengan kepuasan kerja. Hal ini menandakan bahwa ketika seorang karyawan mendapatkan tuntutan waktu (temporal demand) yang tinggi terhadap pekerjaannya, ia juga akan merasa puas dalam bekerja.

Pay merupakan aspek dari kepuasan kerja yang memiliki hubungan yang paling kuat dengan mental workload. Hal ini menandakan bahwa ketika seorang karyawan merasa puas dengan gaji (pay) yang didapatkan, maka akan diikuti dengan tingginya mental workload yang dirasakan oleh karyawan. Ketika karyawan diberi atau mendapatkan gaji dalam jumlah besar, akan diikuti pula dengan bertambah besarnya beban kerja yang ditanggung oleh karyawan, karena pekerjaan dan tuntutan kerja yang diberikan pihak hotel juga akan bertambah.

\section{Saran Teoretis}

Mental workload yang dirasa tinggi memiliki korelasi negatif dengan kepuasan kerja, namun ternyata pada penelitian ini kondisi di hotel X tidak menggambarkan hal tersebut. Kiranya perlu ditelaah lebih detil pada penelitian berikutnya di tempat dan kondisi yang berbeda atau pada model kerja yang sama dengan penelitian ini (di kawasan industri perhotelan), aspek-aspek apa saja yang sekiranya dapat menyebabkan mental workload yang tinggi membuat pekerja semakin bersemangat dan semakin puas dengan pekerjaannya dan tidak menganggapnya sebagai tekanan atau beban secara teoretis. Hal ini berguna agar nantinya dapat diperoleh gambaran atau suatu pola yang dapat menambah referensi teoretis tentang hubungan aspek mental workload dengan aspek kepuasan kerja, misalnya: 
apakah di industri perhotelan, ketika ditelaah aspek lainnya seperti mental demand, effort, performance, frustration level, dan physical demand, akan ditemukan pola bahwa memang benar untuk jenis pekerjaan di bidang jasa tipikal karyawannya mengalami kondisi bahwa semakin ia merasakan beban kerja mental yang tinggi mereka lebih tertantang dan menjadi lebih puas ketika mampu menyelesaikannya atau tidak.

\section{Saran Praktis}

Beban tugas karyawan tidak akan bisa dikurangi jumlahnya karena merupakan hal yang harus diselesaikan oleh karyawan dalam setiap departemen. Hal yang dapat diperbaiki adalah pada pembagian tugas karyawan. Pembagian dapat dilakukan dengan melakukan pemetaan tugas dan tanggung jawab secara lebih tepat. Pemetaan dimulai dengan meninjau ulang tugas karyawan dengan melakukan job analysis sehingga dapat meminimalkan tingginya mental workload yang dirasakan oleh karyawan dengan menimbang kondisi di setiap tempat kerja tidaklah sama. Keseimbangan beban kerja tetap perlu diperhatikan sebagai suatu kondisi ideal dalam bekerja. Terlebih lagi dikarenakan penelitian ini lingkupnya sangat terbatas, sehingga hasil temuan pada penelitian ini sangat mungkin kurang bisa dijadikan acuan untuk model tempat kerja atau hotel lainnya sehingga kondisi kerja ideal dalam tatanan umum tetap perlu diperhatikan, khususnya untuk tipikal hotel budget.

Korelasi positif antara mental workload dan kepuasan kerja berarti pihak hotel dapat meningkatkan kepuasan kerja dengan cara memberikan beban kerja mental yang proporsional terhadap karyawan hotel. Artinya, karyawan harus dipetakan pekerjaannya sehingga antara aktivitas fisik dan mentalnya seimbang, tidak terlalu menguras kapasitas berpikirnya saja atau kapasitas fisiknya saja.

Berdasarkan data ditemukan bahwa temporal demand memiliki hubungan paling kuat dengan kepuasan kerja. Jadi, untuk meningkatkan kepuasan kerja, karyawan dapat diberikan tuntutan waktu yang spesifik dalam penyelesaian tugasnya. Untuk menyeimbangkan tuntutan tersebut, hotel harus tetap memperhatikan waktu istirahat yang diterima karyawan. Selain itu dapat dilakukan pemberian cuti setelah karyawan menyelesaikan pekerjaan yang berat untuk menghindari adanya kelelahan pada karyawan.

\section{REFERENSI}

Altaf, A., \& Awan, M. (2011). Moderating affect of workplace spirituality on the relationship of the job overload and job satisfaction. Journal of Business Ethics, 104(1), 93-94. 
Badan Pusat Statistik. (2015). Data Perkembangan Jumlah Kamar Hotel di Bali Tahun 2011-2014. Denpasar: Badan Pusat Statistik.

Baroka, B. (2013). Hubungan antara beban kerja mental dengan kepuasan kerja pada karyawati pabrik yang sudah berkeluarga (Skripsi tidak dipublikasikan). Universitas Gunadarma, Indonesia.

Cain, B. (2007). A review of the mental workload literature. Toronto, Canada: Defence Research and Development.

Dhania, D. R. (2010). Pengaruh stres kerja, beban kerja terhadap kepuasan kerja (studi pada medical representatif di Kota Kudus). Jurnal Psikologi Universitas Muria Kudus, 1(1), 15-23.

Hart, S. G., \& Staveland, L.E. (1988). Development of NASA-TLX (task load index): Results of empirical and theoretical research. Human Mental Workload. Amsterdam: North Holland Press.

Krejcie, R.V. \& Morgan, D.W. (1970). Determining sample size for reseach activities, Educational and Psychological Measurement, 30(3), 607-610.

Mustapha, N. \& Ghee, W. Y. (2013). Examining faculty workload as antecedent of job satisfaction among academic staff of higher public education in Kelantan, Malaysia. Journal Business and Management Horizons, 1(1), 10-16.

Pusat Data Divisi Sumber Daya Manusia. (2015). Data Karyawan. Bali: Fave Hotel Umalas.

Quick, J. C. \& Quick, J. D. (1984). Organizational stress and preventive management. New York, NY: McGraw-Hill.

Spector, P. E. (1997). Job satisfaction: Application, assessment, causes and consequences. Thousand Oaks, CA: Sage. 